\title{
DEVELOPMENT OF MATHEMATICAL SNAKES AND LADDERS MEDIA TO IMPROVE ELEMENTARY STUDENTS' LEARNING OUTCOMES ON CIRCLE MATERIALS
}

\author{
Mohammad Archi Maulyda ${ }^{1}$, Umar Umar $^{2}$, Vivi Rachmatul Hidayati ${ }^{3}$ \\ ${ }^{1}$ Universitas Mataram ${ }^{2}$ Universitas Mataram, ${ }^{3}$ Universitas Mataram \\ archimaulyda@unram.ac.id, umarelmubaraq90@unram.ac.id, vivirachma@unram.ac.id
}

\begin{abstract}
The success of the teacher in creating an interesting learning atmosphere and can foster a positive attitude of students in participating in this learning is strongly influenced by several factors, one of which is the use of interesting learning media. The purpose of this research is to produce Snakes and Ladders Game Learning Media on the Circle material for grade VI students of SDN 26 Ampenan which is suitable for use based on the assessment of Material Experts, Media Experts, and Students, as well as improving student learning outcomes. Snakes and Ladders Game Learning Media was developed using research and development or Research and Development (R\&D) with the ADDIE development model. At the Development stage, the media developed was assessed for feasibility by 2 Material Experts (lecturers and teachers), 1 Media Expert, 5 Small Group Trial Students, and 25 Large Group Trial Students. Data collection techniques in this development research are through questionnaires and tests. The data obtained from the questionnaire were analyzed descriptively qualitatively and quantitatively. The results of the media assessment based on the Material Experts obtained an average score of 3.6 included in the "Very Eligible" criteria, the Media Experts obtained an average score of 3.1 included in the "Eligible" criteria, and Small Group Trial Students obtained an average score 3.5 is included in the "Very Eligible" criteria, and the Large Group Trial of Students obtained an average score of 3.4 is included in the "Eligible" criteria. Student learning outcomes after using the Snakes and Ladders Game Learning Media that has been developed have increased by $56 \%$. It is concluded that the Snakes and Ladders Game Learning Media is acceptable, feasible and effective to be used as a learning medium.
\end{abstract}

Keywords: Elementary School, Learning Media Development, Snakes and Ladders Game

\section{INTRODUCTION}

Humans need education in life. Education is an effort so that humans can develop their potential through the learning process and/or other ways that are known and recognized by the community. The 1945 Constitution of the Republic of Indonesia Article 31 paragraph (1) states that every citizen has the right to education and paragraph (3) emphasizes that the Government seeks and organizes a national education system that increases faith and piety as well as noble character in the context of educating people's lives. nation governed by law (Mustaghfiroh, 2020). For this reason, all components of the nation must educate the nation's life, which is one of the goals of the Indonesian state.

Mathematics is a universal science that underlies the development of modern technology, has an important role in various disciplines and advances the power of human 
thought. The rapid development in the field of information and communication technology today is based on the development of mathematics in the fields of number theory, algebra, analysis, probability theory and discrete mathematics (Simon, 2020). To master and create technology in the future requires a strong mastery of mathematics from an early age (Sanmee et al., 2021).

However, based on observations made by researchers at SDN 26 Ampenan in March, students were less enthusiastic in participating in the mathematics learning process. The majority of students lack motivation to learn, students are less diligent and easily discouraged in doing the tasks given by the teacher, and lack of interest in learning, such as speaking when the teacher explains. Most students are less active in asking about the subject matter so that students do not understand the material given. Based on the results of interviews with mathematics teachers and students at SDN 26 Ampenan, this was caused by various factors including the teacher still dominantly using the lecture method in the teaching and learning process, the lack of use of learning media so that the use of media was not optimal, only using limited and monotonous worksheets that would make students experience boredom if they are always struggling with monotonous and burdensome routine activities. So that the learning outcomes of students of Group VI SDN 26 Ampenan are still many who are not complete or have not reached the minimum completeness criteria.

The success of the teacher in creating an interesting learning atmosphere and can foster a positive attitude in students in participating in this learning is strongly influenced by several factors, and one of them is the use of interesting learning media. According to Caetano \& Zaro (2018), learning media are everything that can be used to convey messages or information in the teaching and learning process so that it can stimulate students' attention and interest in learning. Meanwhile, according to Farhan et al. (2021), the benefits of learning media in the student learning process are as follows: 1) Learning will attract more students' attention so that it can foster learning motivation, 2) Lesson materials will be clearer in meaning so they can be better understood. by students and can enable them to master and achieve learning objectives, 3) teaching methods will be more varied, not merely verbal communication through the teacher's narrative so that students do not get bored and the teacher does not spend energy, 4) students can do a lot more learning activities because not only listening to teacher descriptions, but also other activities. Judging from these benefits, 
it can be concluded that learning media can improve student learning processes in learning which can improve learning outcomes achieved (Mainali, 2021).

Therefore, it is necessary to develop an interesting new learning media, which has the concept of learning while playing and not boring, so that students are enthusiastic in participating in learning, one of which is by developing Snakes and Ladders Game Media. Snakes and Ladders Game Learning Media was developed because it has several advantages compared to other learning media. According to Dianna Galante (2014), as a learning medium, the use of the snake and ladder game has advantages, including: 1) Snakes and ladders game can used in teaching and learning activities because this activity pleases students so that students are interested in learning while playing, 2) Students can participate in the learning process directly, 3) Snakes and ladders games can be used to help all aspects of student development, one of which is developing mathematical logic intelligence, 4) Snakes and ladders games can stimulate students to learn to solve problems, 5) The use of snakes and ladders games can be done both in class and outside the classroom, 6) The use of snakes and ladders games is easy to do / easy to understand, simple rules, educating if given a good theme and right, entertaining students in a positive and interactive way.

\section{METHOD}

This research uses research and development or Research and Development (R\&D) as the main research paradigm. In this development research, researchers used the ADDIE development model developed by Dick and Carry in (Herdani et al., 2018). The procedure carried out by the ADDIE model consists of five stages, namely Analysis, Design, Development, Implementation and Evaluation which is will explain in the below (Sugiyono, 2016):

\section{Analysis}

The analysis stage is the stage where the researcher analyzes the need for media development and analyzes the feasibility and development requirements. The stages of analysis carried out by the author include three things, namely needs analysis, curriculum analysis, and character analysis of students. The analysis is carried out by first analyzing the state of the teaching materials as the main information in learning and the availability of teaching materials that support the implementation of a lesson. Curriculum analysis pays attention to the characteristics of the curriculum that is being used in a school. This is done 
so that the development carried out can be in accordance with the demands of the applicable curriculum. Then the researcher examines $\mathrm{KD}$ to formulate indicators of learning achievement. Analysis of the character of students to see the attitudes of students towards learning mathematics.

\section{Design}

The second stage of the ADDIE model is the design stage. At this stage, the media will be designed to be developed according to the results of the previous analysis. Next, the design stage is carried out by determining the elements needed in the media and collecting references that will be used in developing the material in the Snake and Ladders media.

\section{Development}

The development stage is the product realization stage. At this stage the development of the Snake and Ladders media was carried out according to the design. After that, the media will be validated by expert lecturers and teachers. In the validation process, the validator uses the instruments that have been prepared in the previous stage. Validation was carried out to assess content and construct validity.

\section{Implementation}

The fourth stage is implementation. The implementation is limited to the schools designated as research sites. The classroom teacher conducts learning using the designed media. The researcher served as an observer and recorded everything on an observation sheet that could be used as a media improvement. After the learning process is complete, students take a test using the questions that have been provided.

\section{Evaluation}

At this stage, the researcher made a final revision of the developed media based on the input obtained from the response questionnaire or field notes on the observation sheet. This is so that the media developed is truly appropriate and can be used by a wider school.

The test subjects in this research on the development of Snakes and Ladders Learning Media are 2 Material Experts (lecturers and teachers), 1 Media Expert, and 5 students for initial trials or small groups, and 25 students for field trials or large groups. This study used instruments in the form of a questionnaire (validation sheet and assessment sheet) and test (pre-test and post-test). The data analysis technique used was descriptive qualitative and quantitative data analysis techniques. Qualitative descriptive analysis technique is used to 
process data in the form of words, namely comments and suggestions from the results of the assessment of Material Experts, Media Experts, and Students. Quantitative descriptive analysis techniques are used to process data in the form of scores obtained through questionnaires and processing test results from students who are the subject of product trials. For the purposes of quantitative analysis, the validation data were scored using a Likert scale.

\section{RESULTS AND DISCUSSION}

This development research uses the ADDIE model with five stages, namely Analysis, Design, Development, Trial, and Evaluation. The analysis phase begins with the analysis of student needs, based on interviews with teachers, information is obtained that:

The use of Snakes and Ladders Game Learning Media has never been done in the mathematics learning process. Meanwhile, based on interviews with students obtained information that students have the ability to play Snakes and Ladders, the researchers set out to develop an interesting learning media, namely Snakes and Ladders Game. This development has been determined for class VI students, and involves students to be active in learning activities so that they can foster student enthusiasm for learning, add knowledge and student learning experiences, which will make student learning outcomes increase/achieve KKM. The next analysis is curriculum and competency analysis (Sudarmilah, 2020).

The curriculum refers to the 2016 curriculum (K-13 Revision). The material developed in this media is a circle which is one of the materials for class VI students. The curriculum includes competency standards and basic competencies for the subject matter of circles, namely, Competency Standards: Determining the elements, parts of the circle and their size. Basic Competence: Determine the elements and parts of a circle. Furthermore, instructional analysis, based on KD on curriculum and competency analysis, indicators used in developing this media, namely: Mentioning the elements and parts of a circle and the length of the line: the center of the circle, the radius, diameter, arc, chord, juring, section and apothem (Powell et al., 2017).

The design stage aims to design learning media in the form of Snakes and Ladders Game on Circle material. At this stage the Product Design Design, Game Device Design (Material, Questions, Answer Keys, and Rules), Arrange Instruments. At this stage of development, an assessment is carried out which aims to produce media that are suitable for use as learning media. After the media is printed, its feasibility is assessed based on 
assessments from Material Experts, Media Experts and Students (Diani et al., 2018; Saputri et al., 2020). The effectiveness of the media is obtained from the results student learning after using the Snakes and Ladders Game Learning Media during the large group trial.

Table 1. Recapitulation of Overall Expert Validation Results

\begin{tabular}{|c|c|c|c|c|c|c|}
\hline \multirow{2}{*}{ No } & \multirow{2}{*}{ Aspect } & \multicolumn{2}{|c|}{ Material Expertise } & \multirow{2}{*}{$\begin{array}{c}\text { Media } \\
\text { Expertise }\end{array}$} & \multirow{2}{*}{$\begin{array}{c}\text { Average } \\
\text { Score }\end{array}$} & \multirow{2}{*}{ Criteria } \\
\hline & & Lecturer & Teacher & & & \\
\hline 1 & Material & 3,5 & 3,5 & - & 3,5 & Very Good \\
\hline 2 & Learning & 3,5 & 3,7 & - & 3,6 & Very Good \\
\hline 3 & Evaluation & 3,8 & 3,2 & - & 3,5 & Very Good \\
\hline 4 & Language & 4 & 3,8 & - & 3,9 & Very Good \\
\hline 5 & Media Innovation & - & - & 3,1 & 3,1 & Good \\
\hline \multirow[t]{2}{*}{6} & $\begin{array}{c}\text { Visual } \\
\text { Communication } \\
\end{array}$ & - & - & 3,1 & 3,1 & Good \\
\hline & Average Score & 3,7 & 3,5 & 3,1 & 3,4 & Good \\
\hline
\end{tabular}

The assessment carried out by the Material Expert is reviewed from the material, learning, evaluation, and language aspects. The assessment carried out by Media Experts is viewed from the aspect of media engineering and visual communication. The assessment carried out by students is viewed from the aspects of material, learning, evaluation, language, media engineering and visual communication. The feasibility of the media developed based on the assessment of the experts can be seen from the validation results of the experts. Expert validation is obtained from a questionnaire to give an assessment of the developed media.

Table 2. Recapitulation of Test Student Assessment Results

\begin{tabular}{|c|c|c|c|c|c|}
\hline No & Aspect & $\begin{array}{c}\text { UC Small } \\
\text { Groups }\end{array}$ & $\begin{array}{l}\text { UC Big } \\
\text { Groups }\end{array}$ & $\begin{array}{l}\text { Average } \\
\text { Score }\end{array}$ & Criteria \\
\hline 1 & Material & 3,5 & 3,4 & 3,4 & Very Good \\
\hline 2 & Learning & 3,7 & 3,6 & 3,6 & Good \\
\hline 3 & Evaluation & 3,2 & 3,0 & 3,1 & Good \\
\hline 4 & Language & 3,5 & 3,5 & 3,5 & Good \\
\hline 5 & Media Inovation & 3,3 & 3,5 & 3,4 & Good \\
\hline 6 & $\begin{array}{c}\text { Visual } \\
\text { Communication }\end{array}$ & 3,6 & 3,5 & 3,5 & Very Good \\
\hline \multicolumn{2}{|r|}{ Average Score } & 3,5 & 3,4 & 3,4 & Good \\
\hline
\end{tabular}

From the presentation of the data in the table above, the average score obtained by the Material Expert is 3.6 with the criteria of "Very Good/Very Decent", while the average score obtained by the Media Expert is 1 with the criteria of "Good/Decent". Furthermore, the trial phase was carried out to determine the feasibility of the media based on student assessments and to determine student learning outcomes after using the developed media. 
From the data presentation in the table above, the average score obtained by the Small Group Trial is 3.5 with the criteria of "Very Good/Very Decent", while the average score obtained by the Large Group Trial is 3.4 with the criteria of "Good/Decent".

Table 3. Recapitulation of Complete Learning Outcomes

\begin{tabular}{|c|c|c|c|}
\hline \multirow{2}{*}{$\begin{array}{c}\text { Various } \\
\text { Assesment }\end{array}$} & \multicolumn{2}{|c|}{ Result } & \multirow{2}{*}{$\begin{array}{c}\text { Classical } \\
\text { Target }\end{array}$} \\
\hline & $\mathrm{T}$ & TT & \\
\hline Pre-Test & 8 & 17 & $32 \%$ \\
\hline Post-Test & 22 & 3 & $88 \%$ \\
\hline
\end{tabular}

Data from student learning outcomes after using the Snakes and Ladders Game learning media has increased. This can be seen in table 3 that the number of students who meet the minimum completeness criteria has increased by $56 \%$.
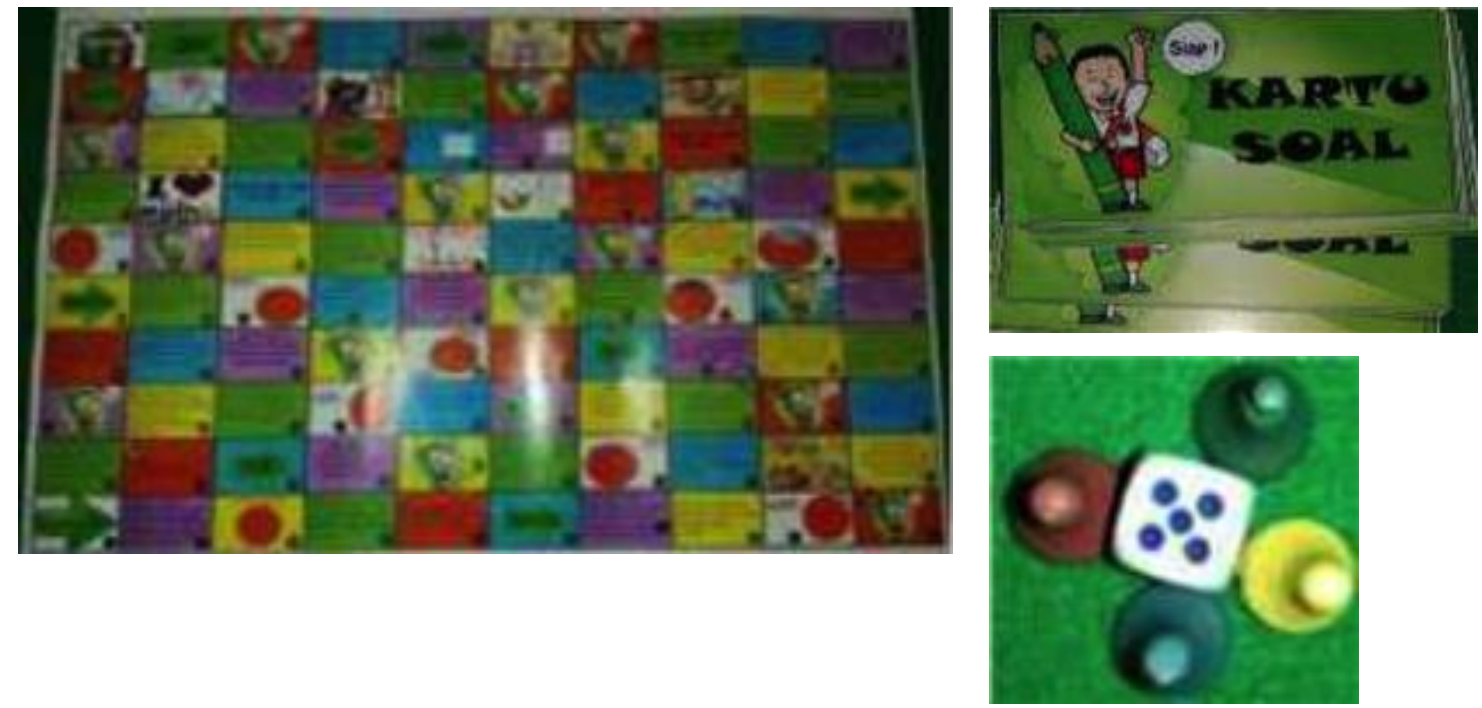

Figure 1. Pictures of Snake and Ladders Game

The last stage, namely the evaluation stage. The activities carried out were: analyzing the assessments of Material Experts, Media Experts, and Students, as well as analyzing the results of pre-test and post-test from students to find out the effectiveness of the Snake Ladder Game Learning Media that was developed. This effectiveness can be seen from the increase in student learning outcomes based on the results of the pretest and posttest assessments given to students. Final product of Game Learning Media (Mathematic Snakes and Ladders) shown in Figure 1. 


\section{CONCLUSION}

Based on the research that has been done, it can be taken as follows: 1) The process of developing Learning Media for Snakes and Ladders Game on the Circle material for grade VI students of SDN 26 Ampenan uses the ADDIE development model, which goes through the following five stages: (a) Stage of Analysis (Analysis), in the first stage the activities carried out are: Student Needs Analysis, Curriculum and Competency Analysis, and Instructional Analysis. (b) Design Phase, in the second phase the activities carried out are Product Design Design, Game Device Development (Material, Questions, Answers, and Rules) and Arrange Instruments. (c) Development Phase, in this third phase the activities carried out are: Product Development, Expert Validation, and Revision I. (d) Implementation Phase (Product Trial). In this fourth stage, the activities carried out are: Initial Trial, Revision II, Field Trial (Large Group). (e) Evaluation stage, in this last stage the activities carried out are: analyzing the assessments of Material Experts, Media Experts, and Students, as well as analyzing the results of pre-test and post-test from students to find out the effectiveness of Snakes and Ladders Game Learning Media developed.

\section{RECOMENDATION}

Several suggestions that researchers can convey in order to develop learning media are as follows: 1) For students, it can be used as a new experience in learning mathematics using the Game Learning Media (Mathematics Snakes and Ladders) so that students are not bored/bored and enthusiastic in participating in learning. 2) Teachers should always be creative and innovate to develop interesting learning media and have the concept of learning while playing such as Snakes and Ladders Game Learning Media and use it to foster student learning enthusiasm so that they can improve student learning outcomes to achieve the specified minimum completeness criteria. 3) For other researchers, it is hoped that they will be able to develop Learning Media for Snakes and Ladders Game on the Circle material which is better than before, both in terms of appearance and material.

\section{REFERENCE}

Caetano, G. A., \& Zaro, M. (2018). The Impact of Using the Interactive Multimedia Book on Mathematics Learning: A Focus on 7th Grade Students Performance. Creative Education, 09(15), 2455-2476. https://doi.org/10.4236/ce.2018.915185

Diani, R., Yuberti, Y., \& Syarlisjiswan, M. R. (2018). Web-Enhanced Course Based on Problem-Based Learning (PBL): Development of Interactive Learning Media for 
Basic Physics II. Jurnal Ilmiah Pendidikan Fisika Al-Biruni, 7(1), 105. https://doi.org/10.24042/jipfalbiruni.v7i1.2849

Dianna Galante. (2014). The Use of the History of Mathematics in the Teaching of Preservice Teachers. Journal of Research in Mathematics Education, 3(24), 110-117. https://doi.org/10.17583/redimat.2014.921

Farhan, M., Satianingsih, R., \& Yustitia, V. (2021). Problem Based Learning On Literacy Mathematics: Experimental Study in Elementary School. Journal of Medives : Journal of Mathematics Education IKIP Veteran Semarang, 5(1), 118. https://doi.org/10.31331/medivesveteran.v5i1.1492

Herdani, T. P., Sartono, N., \& Evriyani, D. (2018). Development of Modified Monopoly Game as a Learning Media On Endocrine System (Research and Development at Senior High School 1 Jakarta). BIOSFER: JURNAL PENDIDIKAN BIOLOGI, 8(1), 20-28. https://doi.org/10.21009/biosferjpb.8-1.3

Mainali, B. (2021). Representation in teaching and learning mathematics. International Journal of Education in Mathematics, Science and Technology, 15(3), 56-78. https://doi.org/10.46328/ijemst.1111

Mustaghfiroh, S. (2020). Konsep "Merdeka Belajar" Perspektif Aliran Progresivisme John Dewey. Jurnal Studi Guru Dan Pembelajaran, 3(1 SE-Articles), 141-147. https://doi.org/10.30605/jsgp.3.1.2020.248

Powell, E. M., Frankel, L. A., \& Hernandez, D. C. (2017). The mediating role of child selfregulation of eating in the relationship between parental use of food as a reward and child emotional overeating. Appetite, 56(3), 452-478. https://doi.org/10.1016/j.appet.2017.02.017

Sanmee, W., Ruangsan, N., \& Kaewketpong, P. (2021). Online Instructional Activities for Creative Internet Use of Tertiary Students in Thailand. Psychology and Education, 58(1), 1453-1457.

Saputri, A., Sukirno, S., Kurniawan, H., \& Probowasito, T. (2020). Developing Android Game-Based Learning Media "Go Accounting" in Accounting Learning. Indonesian Journal on Learning and Advanced Education (IJOLAE), 2(2), 91-99. https://doi.org/10.23917/ijolae.v2i2.9998

Simon, M. A. (2020). Reconstructing Mathematics Pedagogy from a Constructivist Perspective. Journal for Research in Mathematics Education, 25(4), 887-896. https://doi.org/10.5951/jresematheduc.26.2.0114

Sudarmilah, E. (2020). Edugame Application as Vocabulary Learning Media for Deaf Children. International Journal of Advanced Trends in Computer Science and Engineering, 9(2), 1543-1550. https://doi.org/10.30534/ijatcse/2020/97922020

Sugiyono. (2016). Metode penelitian kuantitatif kualitatif dan $R \& D$. Alfa Beta. 